\title{
Limiting Preventive Detention Through Conditional Release: The Unfulfilled Promise of the 1982 Pretrial Services Act
}

\author{
Betsy Kushlan Wanger
}

The preventive detention provision of the 1984 Bail Reform Act, upheld by the Supreme Court in United States $v$. Salerno, ${ }^{1}$ permits federal courts to detain defendants prior to trial on grounds of dangerousness. ${ }^{2}$ Although the 1984 Act expands the permissible bases for holding defendants before trial, ${ }^{3}$ it retains the preference for conditional release ${ }^{4}$ mandated by its statutory predecessor, the Bail Reform Act of $1966 .^{\circ}$ The

1. 107 S. Ct. 2095 (1987).

2. In Salerno, the Court found that detention imposed under $\S 3142(e)$ of the 1984 Bail Reform Act, 18 U.S.C. $\S \S 3141-3150$ (Supp. III 1985), is a regulatory, not punitive, measure, and that the incidents of pretrial detention are not excessive in relation to the regulatory goal of preventing danger to the community that Congress sought to achieve. $107 \mathrm{~S}$. Ct. at 2101.

Debate over the 1984 Act continues. Opponents contend that preventive detention violates the excessive bail clause of the Eighth Amendment, overrides the presumption of innocence, and inflicts punishment based on a prediction of future crime. Supporters maintain that detention hearings enhance fairness to accused persons and the community by requiring courts to confront the risks of pretrial misconduct candidly rather than sub rosa through high money bail. This Note does not join the 1984 Bail Reform Act debate. Rather, it demonstrates that pretrial services are an essential implementation mechanism for the 1984 Bail Reform Act and a crucial determinant of the future direction of the American bail system.

3. Prior to the $1984 \mathrm{Act}$, pretrial detention in noncapital cases could be ordered solely to avoid defendant's failure to appear at trial. S. REP. No. 225, 98th Cong., 1st Sess. 3 (1983), reprinted in 1984 U.S. Code ConG. \& ADMin. News 3182, 3185-86 [hereinafter S. ReP. No. 225].

4. "Conditional release" is the release of a defendant pending trial on a condition or conditions set by a judicial officer. The term "release" is used instead of "bail" to refer not to money bond, but to release on conditions that may or may not include posting money bail, such as release to the custody of a third party or release on the condition that the defendant report regularly to a pretrial services agency.

Congress expressed its preference for conditional release when it passed the Bail Reform Act of 1966. The 1966 Act required that noncapital offenders be released on the least restrictive conditions that would reasonably assure their appearance at trial. See infra notes 29-31 and accompanying text. In order to improve the 1966 Act's effectiveness, Congress passed title II of the 1974 Speedy Trial Act, which directed the Administrative Office of the U.S. Courts to set up experimental pretrial services programs in ten federal judicial districts. Pub. L. No. 93-619, §§ 3152-3156, 88 Stat. 2086, 2088 (1975), amended by 18 U.S.C. §§ 3152-3155 (Supp. III 1985). Pretrial services provide judicial officers with extensive information on defendants' backgrounds to help them make fair and effective pretrial release and detention decisions. Id. § 3154(1). Pretrial services officers may also be assigned to supervise defendants on pretrial release. Id. $\$ 3154(3)$. The success of these experimental programs in allowing safe, conditional release led to the passage of the 1982 Pretrial Services Act, mandating expansion of pretrial services to each federal judicial district. See infra notes 47-53 and accompanying text.

5. 18 U.S.C. $\S \S 3141-3151$ (1982) (amended 1984). 
1984 Act authorizes pretrial detention on grounds of dangerousness only as a last resort. ${ }^{6}$

Two years earlier, Congress passed the Pretrial Services Act of 1982, which mandated the establishment of a pretrial services program in each federal judicial district. ${ }^{8}$ These programs are charged with collecting, verifying and reporting to the court background information about each individual charged with an offense, including information about any danger that the release may pose to any other person or to the community. ${ }^{9}$ Pretrial services officers also recommend conditions for each individual pretrial release, and monitor compliance with the terms of release. Studies based on demonstration pretrial services before the 1982 Act showed both lower detention rates and reduced pretrial flight and crime rates, ${ }^{10}$ even among classes of suspects often characterized as non-releasable. ${ }^{11}$ The 1982 Act reflected Congress' recognition that the courts had been unable to implement adequately the conditional release provisions of the 1966 Bail Reform Act without detailed information and monitoring. ${ }^{12}$

The Salerno case magnifies the importance of pretrial services. Once

6. Congress considered detention appropriate for only those few defendants "as to whom neither the imposition of stringent release conditions nor the prospect of revocation of release" could "reasonably assure" good behavior. S. REP. No. 225, supra note 3, at 6-7. The 1984 Bail Reform Act maintains the 1966 Bail Reform Act's ordered progression from release to detention: the judicial officer must first consider pretrial release or an unsecured appearance bond. 18 U.S.C. § 3142(b) (Supp. III 1985); only if unrestricted release will not reasonably assure the suspect's good behavior may the judicial officer consider release conditions; the suspect must then be released on the least restrictive condition or conditions that will reasonably assure his appearance at trial and community safety. Id. § 3142(c). The 1984 Act includes not only every condition of release set forth in the 1966 Act, but also nine additional conditions, such as reporting on a regular basis to a designated law enforcement agency or a pretrial services agency, complying with a specified curfew, and avoiding all contact with alleged victims of the crime and potential witnesses. Courts are obliged to examine all conditions of release before considering detention of the suspect. Compare 18 U.S.C. $\$ \S 3146(a)(1)-(5)$ (1982) with 18 U.S.C. $\S \S 3142(\mathrm{c})(2)(\mathrm{A})$-(N) (Supp. III 1985).

7. 18 U.S.C. $\S \S 3152-3156$ (1982).

8. The Act incorporates title II of the 1974 Speedy Trial Act, supra note 4, which established demonstration pretrial services agencies in ten federal judicial districts, five as independent agencies and five as part of probation departments. S. REP. No. 77, 97th Cong., 1st Sess. 2-3 (1981) [hereinafter S. REP. No. 77].

9. 18 U.S.C. $\$ 3154$ (1982).

10. See infra note 48 and accompanying text.

11. See infra notes 49-51 and accompanying text.

12. See Extend the Operations of the Pretrial Services Agencies: Hearings Before the Subcomm. on Crime of the House Comm. on the Judiciary, 97th Cong., 1st Sess. 113 (1981) [hereinafter 1981 House Hearings) (testimony of Judge Jack B. Weinstein) ("From the vantage point of any judicial officer, Pretrial Services is primarily a source of information that is vital for the proper operation of the bail determination process. . . . Such information makes possible the informed decisions that Congress clearly had in mind when it passed the Bail Reform Act of 1966."); id. at 119 (testimony of Judge Morris E. Lasker) ("As a result of the availability of such information to the judicial officer and his or her knowledge that pretrial services can and will supervise a defendant where appropriate previous to the time of trial, the judicial officer feels much easier about releasing a defendant on bail."); see also S. REP. No. 77, supra note 8, at 2. Sen. Ervin explained that Congress failed to provide judges with the information and assistance essential to carry out the 1966 Bail Reform Act: "[I]t is common knowledge that many Federal judges are reluctant to release defendants pursuant to the Act and all too often when they do, defendants either commit subsequent crimes or become fugitives. This situation exists because district courts do not have personnel to conduct interviews of [and to supervise] arrested defendants [released prior to trial]." Id. at 2. 
authorized to detain defendants whom they perceive as dangerous, judicial officers may be more likely than in the past to order detention unless they have at their disposal the information and supervising facilities essential to an effective conditional release program. Indeed, since the passage of the Bail Reform Act of 1984, the rate of pretrial detention has increased markedly. ${ }^{13}$ Furthermore, many courts-and seemingly many lawyers - have failed to explore adequately the possibilities of effective conditions of release and methods of supervision in high risk cases, ${ }^{14}$ opting instead for detention. ${ }^{16}$ The extent and quality of services delivered under the 1982 Pretrial Services Act are crucial to determining whether the 1984 Bail Reform Act steers the American bail system toward conditional release-with minimal preventive detention-or toward wholesale detention of the criminally accused. ${ }^{16}$

Although the pretrial services program is critical to the successful administration of the 1984 Bail Reform Act, the statutory command of nationwide services has been largely ignored. Most federal districts currently fail to provide these services in a majority of their cases, and several districts provide no services at all. ${ }^{17}$ This Note explores the promise of the pretrial services program, exposes its lagging implementation, and offers suggestions for improvement. Section I discusses the concept of pretrial services in relation to the historical function of bail and shows that pretrial services provide an effective means of allowing secure release. ${ }^{18}$ Sec-

13. See United States General Accounting Office, Griminal Bail: How Bail. Reform Is WoRking IN SElEcted District Courts 18 (1987) (report on implementation of 1984 Bail Reform Act in four district courts) (overall, 17\% increase in number of defendants detained during pretrial period under new law); see also UnIted States Marshals Service, U.S. Dep't of Justice, United States Marshals Service First Year Implementation of the Comprehensive Crime Control ACT of 1984, at 6 (1986) (32\% increase in number of defendants in U.S. Marshals Service custody in 1985).

14. High risk cases include those in which the judicial officer finds that the defendant is a narcotics dealer, an armed felon, or a person with a record of criminal activity while on bail. S. REP. No. 225 , supra note 3 , at 19 . The 1984 Bail Reform Act creates a rebuttable presumption in such cases that no conditions of release of the accused will reasonably assure the safety of the community. See 18 U.S.C. § 3142(e) (Supp. III 1985).

Throughout this Note, the term "judicial officer" refers to both magistrates and judges. The 1984 Bail Reform Act allows either magistrates or judges to rule on the pretrial dispositions of suspects. 18 U.S.C. $\$ 3041$ (Supp. III 1985). Typically, the accused first appears before a magistrate, after which both the defendant and the government are entitled to review by the district court.

15. See, e.g., United States v. Dominguez, 629 F. Supp. 701 (N.D. Ind. 1986); see also United States v. Young, 647 F. Supp. 1128 (N.D. Ga. 1986) (court fails to consider any conditions of release of two suspects who "have stable family lives, are well educated and enjoy good employment" and neither of whom has a prior criminal conviction); United States v. Colombo, No. 85-244 (E.D.N.Y. Dec. 23, 1985) (order denying release of defendant on conditions that, even if sufficient to assure community safety, would be "burdensome" to defendant and government, and "inconsistent" with 1984 Act's purpose); $c f$. United States v. Orta, 760 F.2d 887 (8th Cir. 1985) (district court erred in interpreting "reasonably assure" standard set forth in 1984 statute as requirement that release conditions "guarantee" community safety and defendant's appearance).

16. See infra text accompanying notes 102-06.

17. See infra text accompanying notes 61-62.

18. This Note uses the term "secure release" to refer to pretrial release with conditions attached to ensure the defendant's good behavior prior to trial. The release is secure because it protects the community from pretrial crime and the judicial system from defendant's failure to appear at trial. 
tion II assesses the current administration of the Pretrial Services Act and demonstrates that its promise remains largely unfulfilled. Section III argues for adherence to the statutory design of the 1982 Act, stressing its importance in facilitating accurate and responsible administration of the 1984 Bail Reform Act.

\section{Origins and Promise of Pretrial Services}

\section{A. The Traditional Idea of Conditional Release}

Conditional release has historically been a central feature of the American bail system. The pretrial services program is a modern expression of a traditional idea-that of the personal surety as security for the defendant's appearance at and good behavior prior to trial.

\section{From Personal Sureties to Bail Bondsmen}

The early American bail system borrowed heavily from traditional British bail practices. ${ }^{10}$ Until the mid-nineteenth century, the surety played the central role in the American bail system. A reputable person from the community would appear before the court to agree to take custody of the defendant under terms set by the court. ${ }^{20}$ Because different defendants posed different types and degrees of risk, courts often adjusted bail conditions to the individual characteristics of the defendant and of the alleged crime. ${ }^{21}$ Although courts had broad authority to deny bail for defendants charged with capital offenses, ${ }^{22}$ they would generally release in a

19. In medieval England, when magistrates traveled from county to county and were often present in a particular locality for only a few months each year, a system of bail developed as a device to free untried prisoners. In order to prevent prolonged detention in primitive jails, sheriffs in England released defendants into the custody of a friend or neighbor-the surety-who was responsible for assuring that the defendant would appear at trial. W. THOMAS, BAIL REFORM IN AMERICA 11 (1976). Initially, if the defendant escaped, the third party custodian was required to surrender himself in the defendant's place. Bail literally meant the bailment or delivery of an accused to jailers of his own choosing. Reese v. United States, 76 U.S. (9 Wall.) 13, 21 (1869) ("the principal is . . . committed to the custody of the sureties as to jailers of his own choosing . ..."). In time, however, the system evolved to permit the surety-who was usually a property owner-to forfeit a promised sum of money instead of himself if the defendant failed to appear at trial. D. FREed \& P. WALD, BaIL IN THE UNITED STATES: 1964, at 1 (1964).

20. The surety would customarily take a pledge, backed by his property, to produce the defendant in court for trial and to supervise his conduct in the interim. D. FREED \& P. WALD, supra note 19, at $1-3$.

21. In determining bail conditions, courts often considered the defendant's record of reliability, the likelihood of conviction, and the potential severity of the sentence. Carbone, Seeing Through the Emperor's New Clothes: Rediscovery of Basic Principles in the Administration of Bail, 34 SYRACUSE $\mathrm{L}$. REv. 517, 517 (1983).

22. The Judiciary Act of 1789 provided:

Upon all arrests in criminal cases, bail shall be admitted, except where punishment may be by death, in which cases it shall not be admitted but by the supreme or a circuit court, or by a justice of the supreme court, or a judge of a district court, who shall exercise their discretion therein, regarding the nature and circumstances of the offense, and of the evidence, and the usages of law.

Judiciary Act of 1789, ch. 20, 1 Stat. 73, 91 (1789). 
form of pretrial custody defendants who were able to find willing custodians. ${ }^{23}$

Due to the increasing difficulty defendants confronted in locating custodians known and acceptable to the courts, ${ }^{24}$ the personal surety system gradually evolved into a commercial bondsman system. ${ }^{25}$ The transformation from personal sureties to commercial bail bondsmen substantially reduced the courts' ability to assess the risks of pretrial release. The pecuniary commitment of a commercial bail bondsman did not necessarily reflect the defendant's own stake in appearing at trial or in ceasing to engage in criminal activity. ${ }^{26}$ Throughout this period, the judicial authority to deny bail was also diminishing as the number of crimes punishable by death was drastically reduced. ${ }^{27}$ Without the secure, supervised release options provided by personal sureties and without broad legal authority to deny bail, many judicial officers set financial conditions of release that exceeded the defendant's ability to pay, effectively ordering sub rosa pretrial detention. $^{28}$

23. Bail (or conditional release) under the surety system was referred to as "the living jail," and was considered more secure than turning the defendant over to the sheriff and holding him in crowded and unsafe jails. Release on bail to the custody of a surety was viewed as a form of detention. See E. DeHaAs, Antiquities of Bail 77 (1940); see also Bail Reform: Hearings on Bills to Amend the Bail Reform Act of 1966 Before the Subcomm. on the Constitution of the Senate Subcomm. on the Judiciary, 97th Cong., 1st Sess. 116-18 (1981) (testimony of Daniel J. Freed) [hereinafter 1981 Senate Hearings].

24. While finding an acceptable personal custodian was easy in the small communities of the early nineteenth century-where the judge would usually know both the defendant and the surety - the increasing urbanization of society during the late nineteenth and early twentieth centuries made this task far more difficult. W. Thomas, supra note 19 , at 12 .

25. See, e.g., Leary v. United States, 224 U.S. 567 (1912) (Supreme Court upholds indemnification contract). Appellant's brief noted that "If a stranger in a strange land could not offer such indemnity, [the defendant] would, in most cases, have no alternative but to submit to deprivation of his liberty without trial." Id. at 569.

The commercial bondsman accepted financial risks for a fee; having never previously met the dcfendant, this entrepreneur was paid by the defendant, and was usually indemnified by contract or collateral from the defendant or his relatives, for agreeing to be responsible for the defendant's appearance in court. D. FREED \& P. WALD, supra note 19 , at 3.

26. Courts initially welcomed these commercial relationships between bail bondsmen and defendants; they prevented overloading of jails with pretrial detainees and allowed courts to refrain from inquiring into the relationship between the hired surety and the defendant. The limitations of the commercial bail system, however, were soon recognized. See, e.g., Leary v. United States, 224 U.S. 567,575 (1912) (recognizing that bondsman's "interest to produce the body of the principal in court is impersonal and wholly pecuniary"); see also Pannell v. United States, 320 F.2d 698, 701-02 (D.C. Cir. 1963) (Bazelon, J., concurring) (because bondsman decides whether to require collateral for bond, defendant may have no real financial stake in complying with conditions of bond, regardless of amount; hence court does not decide-or even know-whether higher bond for a particular defendant means greater stake and greater incentive not to flee). A surety's standing up for a defendant was seen as a testimonial to the defendant's character and reliability; a bail bondsman, by contrast, may prefer taking responsibility for a career criminal because if the suspect pays his money and shows up in court, his continual engagement in crime means that there will be more business for the bail bondsman. 1981 Senate Hearings, supra note 23, at 122.

27. See Mitchell, Bail Reform and the Constitutionality of Pretrial Detention, 55 VA. L. REV, 1223, 1229-30 (1969); see also S. REP. No. 147, 98th Cong., ist Sess. 20 (1983) [hereinafter S. REP. No. 147].

28. See National Center for State Courts, An Evaluation of Policy Related Research on the Effectiveness of Pretrial Release Programs 8 (1975); see also U.S. Dep'T 


\section{Return to Conditional Release: The 1966 Bail Reform Act}

Designed primarily to reduce the excessive judicial reliance on high money bail, the Bail Reform Act of $1966^{29}$ placed renewed emphasis on custodial supervision to facilitate safe release. This Act required judicial officers to consider a host of release conditions ${ }^{30}$ and to release suspects under the least restrictive conditions that would reasonably assure their appearance at trial. ${ }^{31}$

In practice, however, judicial officers encountered great difficulties in setting the terms of release and in ensuring that the conditions were met. Although the 1966 Act specified numerous conditions ${ }^{32}$ and factors ${ }^{33}$ that the court had to consider, it failed to provide any new mechanisms for collecting and verifying the information. Many district courts did not have the personnel to conduct interviews with arrested defendants, nor-except in the District of Golumbia-did they have any agencies charged with supervising bail conditions for defendants released prior to trial. ${ }^{34}$ The Administrative Office of the U.S. Courts did make available in all districts forms specifying the kinds of information judicial officers should consider

of Justice, The Attrorney General's TAsk Force on Violent Crime: Final Report (1981). The Report recognized this sub rosa form of pretrial detention, observing that "there is a widespread practice of detaining particularly dangerous defendants by the setting of high money bonds to assure appearance." Id. at 51. See also Hearings on Amendments to the Bail Reform Act before the Subcomm. on Constitutional Rights of the Senate Comm. on the Judiciary, 91st Cong., 1st Sess. 220-21 (1969). This system penalized the poor who could not afford to buy their freedom by paying the premium for a bail bond. R. GoldFarB, RANSOM 16-19, 32-40 (1965).

29. 18 U.S.C. $\$ \S 3141-3151$ (1982) (amended 1984).

30. The Act provided for release on personal recognizance or execution of an unsecured appearance bond; third party custody; restrictions on travel, association or place of abode; execution of an appearance bond; execution of a bail bond; or any other condition deemed reasonably necessary to assure appearance as required. The judicial officer was required to consider each conditional release provision before addressing the issue of detention. Id. $\S 3146(\mathrm{a})$.

31. The [1966] Bail Reform Act creates a presumption in favor of release on personal recognizance or an unsecured appearance bond. It provides that when a judicial officer determines that such a release will not insure the appearance of the accused, the judicial officer shall consider, in order of increasing limitation on the defendant's freedom, a number of release conditions set forth in the statute, and shall impose the first condition or conditions that will reasonably assure the appearance of the accused.

1981 House Hearings, supra note 12, at 1 (opening statement of Chairman Hughes).

32. See supra note 30 .

33. In determining which conditions of release will reasonably assure appearance, the judicial officer shall, on the basis of available information, take into account the nature and circumstances of the offense charged, the weight of the evidence against the accused, the accused's family ties, employment, financial resources, character and mental condition, the length of his residence in the community, his record of convictions, and his record of appearance at court proceedings or of flight to avoid prosecution or failure to appear at court proceedings.

18 U.S.C. $\S 3146(\mathrm{~b})$ (1982).

34. See S. REP. No. 77, supra note 8, at 2. When Congress passed the 1966 Bail Reform Act, it also created the D.C. Bail Agency to assist the courts in the District of Columbia with implementation of the 1966 Act (made applicable to the local courts by explicit provision of the Agency's enabling legislation); see also W. ThOMAs, supra note 19, at 174. See generally RePORT OF THE JUdiciaL Council Committee to Study the Operation of the Bail Reform Act in the District of Columbia (1969), reprinted in Preventive Detention: Hearings Before the Subcomm. on Constitutional Rights of the Senate Comm. on the Judiciary, 91st Cong., 2d Sess. 703, 717-18 (1970) [hereinafter 1970 Senate Hearings]. 
in determining the conditions of release that would reasonably assure appearance. ${ }^{35}$ Critics have charged, however, that federal agents, who were not trained to collect and report the information necessary for bail determinations, often presented unverified information to the court. ${ }^{36}$ In addition, presentations by lawyers were often ineffective. ${ }^{37}$ Without complete and verified information, judicial officers were reluctant to risk release and continued to order high money bail..$^{38}$

\section{B. Refinements to the Traditional Approach: The 1974 Speedy Trial Act and Demonstration Pretrial Services Agencies}

In 1974, Congress passed the Speedy Trial Act, ${ }^{39}$ which was intended to reduce the risks of crime and the danger of recidivism by expediting trials and providing supervision for defendants released pending trial. ${ }^{40}$ Title I of the Act limited the permissible period of delay between arrest and trial, ${ }^{41}$ and title II directed the Administrative Office of the U.S. Courts to set up demonstration pretrial services programs in ten specified federal judicial districts. ${ }^{42}$ Congress intended title II of the 1974 Act to enhance operation of the 1966 Bail Reform Act by providing judges with information necessary for conditional release decisions authorized under the 1966 Act. $^{43}$ The pretrial services programs were charged with collecting, verifying and reporting to the judicial officer background information

35. Form I listed questions designed to assist the judicial officer in obtaining information from the representative of the United States concerning the nature and circumstances of the offense charged, the weight of the evidence against the accused, and the circumstances of the arrest. Form II listed questions designed to assist the judicial officer in obtaining information from the defendant concerning other factors specified in the statute, i.e. background, family ties, employment history, and criminal record. A.B.A. Project on Minimum Standards for Criminal Justice, Standards Relating TO PRETRIAl ReLeASE apps. A \& B (1968), reprinted in 1970 Senate Hearings, supra note 34, at 690-95.

36. Set, e.g., Interview with Illa Jeanne Sensenich, Federal Magistrate in W.D. Pa. (Dec. 11, 1986).

37. Defense lawyers, who were often appointed or retained at the time of the bail hearing, rarely knew much about the case or about the bail circumstances. Government attorneys also often lacked full information at the time of the hearing. See H.R. REP. No. 56, 97th Cong., 1st Sess. 8 (1981) [hereinafter H.R. REP. No. 56] (magistrates commenting on difficulties of relying on lawyers for facts to form basis of informed bail decision).

38. See S. REP. No. 77, supra note 8 , at 2 ; see also Interview with Bruce Beaudin, former director of District of Columbia Pretrial Services Agency (Feb. 2, 1987). The 1984 Bail Reform Act was intended to curtail this sub rosa detention. "[T]he judicial officer may not impose a financial condition that results in the pretrial detention of the person." 18 U.S.C. $\$ 3142$ (c) (Supp. III 1985).

39. Pub. L. No. 93-619, §§ 3152-3156, $\S \S 3161-3174,88$ Stat. 2076, 2088 (1975), amended by 18 U.S.C. $\$ \S 3152-3155$ (Supp. III 1985).

40. Id. (statement of purposes). See Hearings Before the Subcomm. on Constitutional Rights of the Senate Comm. on the Judiciary, 92nd Cong., 1st Sess. 2 (1971) [hereinafter 1971 Senate Hearings]; id. at 20 (Chairman Ervin discussing role of title II of 1974 Speedy Trial Act in reducing recidivism).

41. 18 U.S.G. $\$ \S 3161-3174$ (Supp. III 1985).

42. Pub. L. No. 93-619, $\S \S 3152-3156,88$ Stat. 2086, 2088 (1975).

43. See 1971 Senate Hearings, supra note 40, at 135 (Chairman Ervin stating that in retrospect 1966 Bail Reform Act should have had implementation mechanism). 
about criminal suspects ${ }^{44}$ as well as with recommending appropriate release conditions. ${ }^{45}$ The demonstration programs were also responsible for (1) supervising and providing supportive services for defendants released in their custody, or serving as coordinators for other local agencies acting as custodians; (2) assisting released suspects to obtain employment, medical, legal or social services; and (3) reviewing, modifying and resubmitting their reports and recommendations in response to any apparent violations of pretrial release conditions. ${ }^{46}$

The demonstration agencies were well-received by judicial officers, lawyers, and administrators, all of whom reported that the agencies improved the operation of the 1966 Bail Reform Act and enabled courts to make better informed decisions. ${ }^{47}$ Furthermore, statistical reports on the demonstration agencies showed a reduction in rates of detention accompanied by a decrease in the rates of rearrest and failure to appear at trial. ${ }^{48}$ Reports also showed a significant drop in detainees held until disposition among

44. The report would include information on employment, community activities, prior convictions, and record of court appearances. Id. at 145.

45. Recommendations for conditional release might include entering rehabilitation programs, remaining in the custody of a designated third person, restricting personal associations, or reporting to a pretrial services agency. Id.

46. Pub. L. No. 93-619, § 3154, 88 Stat. 2087, 2088 (1975).

47. See Administrative Office of the United States Courts, Implementation of TitLe II of the Speedy Trial ACT of 1974 20-24 (1979) [hereinafter Trtle II ReP.]. Judge Tjoflat, Chairman of the Judicial Conference's Committee on the Administration of the Probation System, has testified:

[T]hose involved in the everyday workings of pretrial services agencies in these ten districts, ... judges, magistrates, probation officers, defense counsel and prosecutors, [report that] the considerations mandated in the Bail Reform Act which go to the issue of bail ... are now being brought to the attention of the judicial officer before a bail decision is made, and the quality of justice is vastly improved. . . . [T] he administration of justice is far better served when a magistrate or judge, setting conditions of bail under the Bail Reform Act of 1966, has sufficient accurate and objective information regarding the defendant, his background, the offense and all other evidence that relates to the question of whether he will appear for trial. The system is far better served when the judge can make an informed decision and pretrial services has made a major step in that direction.

1981 House Hearings, supra note 12, at 12; see also Operations of the Pretrial Services Agencies: Hearings on H.R. 7084 Before the Subcomm. on Crime of the House Comm. on the Judiciary, 96th Cong., 2d Sess. 204-24 (1980) [hereinafter 1980 House Hearings] (statements by Bruce Beaudin, former director of the D.C. Pretrial Services Agency, and Jean Dwyer, a federal magistrate in the District of Columbia). See generally S. REP. No. 77, supra note 8.

48. The following data from TITLE II REP., supra note 47, were summarized in H.R. REP. No. 56, supra note 37 , at 4 . They measure the performance of demonstration pretrial services programs from the first reporting period (1975-76) to the last reporting period before the Final Report was published (1977-78): 
drug offenders; ${ }^{49}$ greater numbers of drug offenders, often characterized as high risks for pretrial crime, ${ }^{50}$ were released where pretrial services were in effect, yet failure to appear and pretrial arrest rates did not rise. ${ }^{\mathbf{3 1}}$

\begin{tabular}{|c|c|c|c|}
\hline \multicolumn{4}{|l|}{ [In percent] } \\
\hline & $75-76$ & $' 77-78$ & $\begin{array}{c}\text { Net } \\
\text { Change }\end{array}$ \\
\hline \multicolumn{4}{|l|}{ 1. Rates of reports submitted by the initial bail hearing: } \\
\hline Independent $\ldots \ldots \ldots \ldots \ldots \ldots \ldots \ldots \ldots \ldots \ldots$ & 64.4 & 87.2 & +35.0 \\
\hline Probation $\ldots \ldots \ldots, \ldots, \cdots \cdots \cdots, \ldots$ & 70.5 & 74.4 & +5.6 \\
\hline \multicolumn{4}{|l|}{ 2. Rates of bail recommendations submitted: } \\
\hline Independent $\ldots \ldots \ldots \ldots \ldots \ldots \ldots$ & 59.9 & 79.6 & +32.8 \\
\hline Probation & 59.8 & 60.9 & +1.8 \\
\hline \multicolumn{4}{|l|}{ 3. Rearrest rates: } \\
\hline Independent. & 7.9 & 3.4 & -56.9 \\
\hline Probation .......... & 9.1 & 4.5 & -50.5 \\
\hline \multicolumn{4}{|l|}{ 4. Failure to appear rates: } \\
\hline Independent $\ldots \ldots \ldots$ & 3.8 & 3.4 & -10.5 \\
\hline Probation ........... & 6.8 & 2.4 & -64.0 \\
\hline \multicolumn{4}{|l|}{ 5. Initial release rates: } \\
\hline Independent .... & 71.9 & 76.9 & +6.9 \\
\hline Probation .......... & 65.1 & 65.5 & +.6 \\
\hline \multicolumn{4}{|l|}{ 6. ${ }^{*}$ Detention rates: } \\
\hline Independent... & 35.2 & 24.4 & -10.8 \\
\hline Probation ... & 52.3 & 43.5 & -8.8 \\
\hline
\end{tabular}

*Detained during any part or all of period before trial. TrTLE II ReP., supra note 47, at 43.

The trend toward overall improvements in these areas continued. For the period of 1979-80, the rate of reports submitted by the initial bail hearing rose to $89.5 \%$ in independent districts; in probation districts, it fell slightly to $73.5 \%$. The rate of bail recommendations submitted in independent districts grew to $88.2 \%$; in probation districts, it grew to $68.7 \%$. The rate of rearrests fell to $3.4 \%$ in independent districts, and $3.2 \%$ in probation districts. The failure to appear rate fell to $1.0 \%$ in independent districts, and $1.6 \%$ in probation districts. The rate of initial release in independent districts rose to $77.5 \%$, and in probation districts rose to $74.8 \%$. See also TrTLE II REP., supra note 47 , at 54-55 (findings of Administrative Office of the U.S. Courts showed that between 1973-74 and 1977-78, pretrial services districts-both independent and probation-run-showed greater reductions in rates of crime on bail and failure to appear than nors-pretrial services districts); $i d$. app. A, tables C5, C6 (pretrial services demonstration districts reduced failure to appear and crime on bail by approximately $50 \%$ between $1974-75$ and 1977-78).

49. See TItLE II ReP., supra note 47, app. B, table III-3. The rate for "never released" defendants with drug-related current offenses was $32.9 \%$ before the demonstration agencies were implemented and $23.5 \%$ afterwards. Drug-related offenses include possession, distribution, and conspiracy. Id.

50. See Bail Reform and Narcotics: Hearings Before the House Select Comm. on Narcotics Abuse and Control, 97th Cong., 1st Sess. 45 (1981) (testimony of Magistrate Palermo urging discretion for judicial officers in drug and other types of cases to consider specific issues of danger to the community and violation of another crime while on bail).

51. See supra note 48 (overall failure to appear and rearrest rates lower under pretrial services programs); see also Report ON THE INCIDENCE of FAILURE TO APPEAR BY DEFENDANTS Charged with Drug Crimes in the Southern District of Florida, reprinted in 1981 Senate Hearings, supra note 23, at 64 (failure to appear rate eight times lower where pretrial services available); Bail Reform and Narcotics: Hearings Before the House Select Comm. on Narcotics Abuse and Control, supra note 50, at 43 (magistrate testifying that pretrial services program is effective method of controlling misbehavior among narcotics suspects).

While pretrial arrest rates may not be the same as pretrial crime rates, pretrial arrest rates do function as a rough indicator of pretrial crime. 


\section{The 1982 Pretrial Services Act and the Unfulfilled Potential of Conditional Release}

\section{A. Considerations of Dangerousness Under the 1982 Pretrial Services Act}

The effectiveness of the demonstration agencies fueled the passage of the Pretrial Services Act of 1982, , $^{\text {s2 }}$ which undertook to expand pretrial services in all federal judicial districts ${ }^{\mathrm{5s}}$ and endorsed the principle of safe, conditional release. Two of the 1982 Act's central objectives were to reduce the risks that released defendants (1) would fail to appear at trial or (2) would engage in criminal activity before trial. ${ }^{54}$ While the 1966 Bail Reform Act had squarely addressed the first goal of reducing pretrial flight, ${ }^{\text {ob }}$ the 1982 Pretrial Services Act was the first federal statute to confront the second problem of crime on bail. For the first time, Congress required dangerousness to be a factor considered for pretrial inquiry and report. ${ }^{58}$ Congress seems to have predicated the collection of information on dangerousness in the 1982 Act on its anticipation of amendments to the 1966 Bail Reform Act. ${ }^{87}$ The 1982 Pretrial Services Act was thus structured to serve as an implementation mechanism both for the original 1966 Bail Reform Act, which emphasized conditional release, as well as for its amended version, which was expected to allow an explicit consideration of dangerousness in limited circumstances.

Designed to implement the 1966 Bail Reform Act and its anticipated successor, pretrial services promised the best of both worlds: by reducing crime on bail and failure to appear rates, pretrial services programs would respond to community fears; by giving operative meaning to conditional release, pretrial services would preserve the principle that suspects ought

52. 18 U.S.C. $\$ \S 3152-3156$ (1982).

53. See S. REP. No. 77, supra note 8 , at 1. The District of Columbia was excluded, however, because it had a pretrial program in operation before Congress passed the Speedy Trial Act of 1974. District of Columbia Court Reform and Criminal Procedure Act of 1970, 23 D.C. CoDE ANN. §§ 1321-1332 (1970).

54. See S. REP. No. 77 , supra note 8 , at 1.

55. See supra notes $29-31$ and accompanying text.

56. The Pretrial Services Act charges agencies with "collect[ing] . . . information pertaining to the pretrial release of each individual charged with an offense, including information relating to any danger that the release of such person may pose to any other person or the community, and recommend[ing] appropriate release conditions for such individual." 18 U.S.C. § 3154(1) (1982).

57. Even before it passed the $1982 \mathrm{Act}$, Congress issued forewarning of further legislation aimed at reducing crime on bail. See statement of Senator Biden:

Establishing pretrial services in every district will not be the end of Congress' responsibility to reduce crime on bail. We [sic] know, for example, that increased pretrial supervision will not decrease the likelihood that some types of defendants will commit subsequent crimes while on bail. Therefore, Congress will soon consider proposals which will authorize judges to consider whether certain defendants pose such a great danger to the community that preventive detention is necessary.

1981 Senate Hearing, supra note 23, at 367; see also H.R. REP. No. 56, supra note 37, at 16 (quoting Mr. Sawyer) ("If we do amend the Bail Reform Act, then if we don't [authorize pretrial services to inform the court about the defendant's alleged danger to the community], we will have to come back and reamend this Act to get them the information."). 
not be deprived of liberty prior to conviction. In addition, as the demonstration programs had shown, a pretrial services program would lower administrative costs incurred during pretrial proceedings because pretrial supervision had been on average less expensive than pretrial detention. ${ }^{\mathbf{5 8}}$ With the support of numerous associations involved in the administration of criminal justice, ${ }^{59}$ pretrial services appeared to have a bright future. Expectations were high for the 1982 Act's effectiveness in continuing and strengthening secure, conditional pretrial release.

\section{B. Failed Implementation of the 1982 Pretrial Services Act}

Despite the proven effectiveness and tremendous promise of pretrial services, the congressional mandate of nationwide implementation of the 1982 Act has not been fulfilled. Not only are there wide disparities in availability and quality of pretrial services among the federal districts, but problems with organization and funding have severely limited the program's administration overall.

\section{Extent of Implementation}

Recent federal reports document the poor implementation of pretrial services. While the statute requires that pretrial services officers collect and verify information about each suspect before the pretrial release hear-

58. According to studies by the Administrative Office of the U.S. Courts, in 1981 the average cost of 100 days of pretrial detention was $\$ 2000$, while the average cost of 100 days of pretrial release and supervision by a pretrial services agency was only $\$ 400.1981$ House Hearings, supra note 12 , at 17-18 (statement of Guy Willetts, Chief of Pretrial Services Branch). Additional studies show that thorough administration of the Pretrial Services Act reduces the costs of unnecessary detention at a rate of $\$ 28$ to $\$ 30$ per day per defendant. See id.; see also H.R. REP. No. 56, supra note 37, at 5 .

Pretrial services brought substantial reductions in costs in the demonstration districts established by the 1974 Speedy Trial Act. Comparing figures for two years immediately before the Act and five years under the Act, using a constant figure of 8,000 defendants per year, and accounting for inflation, an analysis by the Administrative Office of the U.S. Courts showed a reduction of approximately $67 \%$ in the cost of pretrial detention in the ten demonstration districts, from $\$ 4,368,902$ per year to $\$ 1,919,386$. "No attempt has been made to quantify the savings brought about by the $50 \%$ reduction in crime on bail (thereby reducing losses to victims) or the similar reduction in failure to appear for trial (saving time and expenses for court personnel), but such savings are clear." Id. Furthermore, the supervision and cooperation provided from the time of pretrial release to final disposition may positively influence the conduct of the defendant, which may in turn affect the outcome of the final sentence. Studies have shown that defendants released prior to trial receive lower sentences than defendants detained before trial. See, e.g., Rankin, The Effect of Pretrial Detention, 39 N.Y.U. L. REv. 641 (1964) (describing causal relationship between pretrial detention and unfavorable disposition); Wald, Pretrial Detention and Ultimate Freedom: A Statistical Study, 39 N.Y.U. L. REv. 631 (1964) (examining impact of prior detention on sentencing process). Moreover, implementation of the Pretrial Services Act and increased pretrial release would help alleviate jail overcrowding, thereby improving detention conditions and further reducing administrative costs within the criminal justice system.

59. The following organizations recommended the establishment of widespread pretrial services: the Administrative Office of the U.S. Courts, the Judicial Conference of the United States, the National District Attorneys' Association, the Federal Probation Officers' Association, the American Correctional Association, the National Association of Counties, the National Advisory Commission on Criminal Justice, Standards and Goals, and the American Bar Association. See S. REP. No. 77, supra note 8 , at $6-7$. 
ing, ${ }^{60}$ a report by the U.S. General Accounting Office showed that only 7 of the 93 federal districts contacted more than $90 \%$ of defendants before bail hearings; 54 contacted fewer than $50 \%$ of defendants; 26 , fewer than 25\%; and 7 districts reported delivery of no pretrial services at all. ${ }^{61}$ The Administrative Office of the U.S. Courts reported that overall in 1984, there were 43,851 criminal defendants eligible for pretrial services. Of this total, 21,158 defendants (48\%) were contacted for interviews before their bail hearings, 4,192 defendants $(10 \%)$ were contacted after their bail hearings, and 17,668 defendants (40\%) were not contacted at all. ${ }^{62}$

The reports of individual districts ${ }^{63}$ confirm the variation in delivery of services. In the Northern District of California, for example, probation workers completed bail investigations for only $25 \%$ of the persons charged with crimes in $1985 .^{64}$ This district's 1985 annual report provides very little other information. In the Southern District of New York, however, pretrial services workers fully interviewed $89 \%$ of the defendants for whom bail was set or continued during the 1985-86 period. ${ }^{65}$ This district's report contains extensive information on district court filings and pretrial proceedings. These two annual reports illustrate wide disparities in performance of pretrial services programs. ${ }^{B B}$

\section{Organization and Funding of Pretrial Services: Probation Departments v. Independent Agencies}

Title II of the 1974 Speedy Trial Act set up ten demonstration pretrial services agencies. In five districts, the powers of the pretrial services programs were vested in the probation division of the Administrative Office of the U.S. Courts and each program operated under the general supervision

60. 18 U.S.C. $\S 3154(1)(1982)$.

61. United States General Accounting Office, Federal District Courts' Implementation of the 1982 Pretrial Services Act app. II at 19-21 (1985) [hereinafter GAO StUdy] (to date, only comprehensive federal study of implementation of 1982 Act in all federal districts).

62. Id. app. I at 4.

63. The 1982 Act requires each district to submit an annual report to the chief judge of the district court and the director of the Administrative Office of the U.S. Courts concerning the administration and operation of pretrial services. 18 U.S.C. $\S 3155$ (1982).

64. Chief U.S. Probation Officer, Annual Report for the Year Ending June 30, 1985: Administration and Operation of Pretrial Services in the Northern District of CaliFORNIA (1985). During this twelve month period, 1,375 persons were charged with crimes, and 345 bail investigations were completed. Id. at 2 .

65. Chief U.S. Pretrial Services Officer, Southern District of New York: Pretrial Services Agency Annual Report Covering the Period 7/1/85 to 6/30/86 (1986). During this period, there were 2,187 criminal defendant filings, but bail proceedings were not conducted in 71 cases. Of the 2,116 defendants for whom bail was set or continued, 1,892 were interviewed by pretrial services officers. Id. at 5 .

66. The discrepancies in these data, however, may also result from poor reporting practices within a particular district and lack of uniform national reporting guidelines. In addition, the discrepancies may reflect in part low reporting rates. The data in the GAO report were provided by the Adminis-. trative Office's Pretrial Services Data System, which does not contain information on some misdemeanor cases handled by magistrates. In addition, some judicial districts fail to submit pretrial information in a timely manner. See GAO STUDY, supra note 61 , app. I at 5. 
of the district's chief probation officer. ${ }^{67}$ In the other five districts, the powers of the pretrial services programs were vested in independent boards of trustees, appointed in accordance with the provisions of the Act, and each program operated under a chief pretrial services officer selected by the board ${ }^{68}$ Pretrial services officers were to be trained to elicit and verify facts for judicial officers to consider in formulating pretrial release and detention decisions.

Independent agencies providing pretrial services under the 1974 Act received more favorable performance reports than did probation-run programs. ${ }^{68}$ Because most probation offices are already overburdened, ${ }^{70}$ and because probation philosophy and practices have been developed to deal with convicted criminals, not with presumptively innocent defendants, ${ }^{71}$ an independent agency can better perform pretrial services. Experts in the field overwhelmingly recommended that pretrial services operate independently from probation services, except in those districts in which a light caseload would not warrant a separate unit. ${ }^{72}$ Probation officials, however, reported to Congress that pretrial services could be provided by pro-

67. Pub. L. No. 93-619, § 3153(b), 88 Stat. 2086 (1975).

68. Id. $\S 3153(\mathrm{a})$.

69. See Title II Rep., supra note 47, at 28-42 (more extensive services performed in districts with independent pretrial services agencies than in districts operated under direction of probation service; independent agencies submitted reports on higher percentage of defendants interviewed in their districts, submitted recommendations more frequently for non-financial conditions of release, and completed more cases by issuing initial releases of defendants).

70. Judge Tjoflat noted that independent pretrial services programs were more effective than probation department pretrial services programs because probation pretrial services must serve two masters: "Since the probation function is being performed essentially for the district judge and the bail function is being performed for the magistrate, the probation function gets first call . . . [E]specially in larger districts . . . if probation work is lagging behind, that work will get done first." Implementation of the Pretrial Services Act of 1982: Hearings before Subcomm. on Crime of the House Comm. on the Judiciary, 98th Cong., 2d Sess. 32 (1984) [hereinafter 1984 House Hearings]. Concern regarding the ability of probation officers to perform both pretrial and probation functions is further warranted by anticipation of the effects of new federal sentencing guidelines required by the Comprehensive Crime Control Act of 1984, Pub. L. No. 98-473, 98 Stat. 1837 (1984). Title II of this Act-Sentencing Reform-requires probation officers to complete timely and detailed presentence reports. Guideline sentencing is expected to increase significantly the workload of probation departments. See Hearings on Sentencing Guidelines before the Subcomm. on Criminal Justice of the House Comm. on the Judiciary, 100th Cong., 1st Sess. (publication forthcoming) (July 23, 1987 prepared statement of Judge Tjoflat, Chairman of the Comm. on the Admin. of the Probation System of the Judicial Conference of the United States, at 4) (on file with author).

71. Because probation departments and pretrial services agencies have different functions in the criminal justice system, presentence reports and probation/parole supervision should be quite different from pretrial services reports and pretrial supervision:

[T]he attitudes, policies and procedures required to assure that the accused's rights are not violated must be delicately balanced with the need for protection of society and the timely court process. The attitudes, policies, and procedures required to make sentencing recommendations and supervise convicted offenders on probation are different; the former is based upon a presumption of innocence with its concomitant presumption of release on recognizance while the latter is based upon a final determination of guilt where the burden on the defendant to justify release into the community is greater.

Hearings before the Subcomm. on Criminal Justice of the Senate Comm. on the Judiciary, 96th Cong., 2nd Sess. 3 (1980).

72. See S. REP. No. 77, supra note 8 at 10; see also 1984 House Hearings, supra note 70 , at 35. 
bation officials with no additional resources or personnel. ${ }^{73}$ While Congress clearly favored implementation through newly created independent agencies wherever pre-existing resources were inadequate, ${ }^{74}$ the final version of the 1982 Act allowed individual districts themselves to choose initially between delivery by probation or by independent agencies, with the presumption that the latter would be appropriate for most districts. ${ }^{75} \mathrm{Re}-$ gardless of the means chosen, however, Congress made the delivery of services mandatory. ${ }^{76}$

Although the demonstration independent agencies were more effective than probation programs in delivering pretrial services and although Congress evidently preferred independent agencies, the vast majority of districts have chosen to use existing probation agencies to deliver pretrial services ${ }^{77}$ even in districts with heavy caseloads and overworked probation officers. ${ }^{78}$ As of September 1985, only nine districts had chosen to implement the Act by establishing independent agencies, ${ }^{79}$ entitling them to fed-

73. See 1980 House Hearings, supra note 47, at 9-10. In fact, the Federal Probation Officers Association asserted to Congress that pretrial services could be provided at a lower cost by assigning the function to existing probation agencies. Id.; see also 1984 House Hearings, supra note 70, at 33.

74. S. REP. No. 77 , supra note 8 , at 8 .

75. Congress gave great weight to virtually unanimous reports that independent districts worked better than probation districts, but it also was convinced by probation officials that, in some districts, probation departments could handle delivery of services on their own, with no additional personnel. Therefore, Congress drafted the Act to allow both options, "depending upon the caseloads, workloads, burdens, individual administrative practices and other factors which prevail in each individual district." S. REP. No. 77, supra note 8, at 9 (quoting William E. Foley, Dir. of the Admin. Office of the U.S. Courts).

The 1982 Act specifically requires each district to implement a pretrial services program, supervised by either a chief pretrial services officer or a chief probation officer, a choice that was to be reevaluated after the first 18 months of operation. 18 U.S.C. $\$ 3152$ (a) (1982). If, at the end of 18 months, the appropriate district court and circuit judicial council determine that the probation office is unable to handle pretrial services with existing resources, the 1982 Act requires that independent agencies be established. Id. $\S \S 3152$ (b), (c); see also S. REP. No. 77, supra note 8, at 9-10 (discussing need for separate agencies).

76. Congress considered the possibility that specific categories of offenders-such as misdemeanants-might not need to be interviewed or supervised by pretrial services personnel. Data presented to Congress, however, indicated that conventional wisdom about which cases could be disregarded was not reliable. See 1981 House Hearings, supra note 12, at 176 (testimony of Dan Ryan, Pretrial Services Specialist with the Admin. Office of the U.S. Courts).

77. As of September 1985, 84 of the 93 federal districts reported delivering pretrial services through their probation offices. See GAO STUDy, supra note 61, app. II, Table II.1, at 19-21. Five districts in 1986 and five in 1987 switched from probation offices to independent agencies in order to procure funding necessary to carry out the requirements of the 1982 Act.

78. In the Southern District of Ohio, for example, the Probation Office began to perform pretrial services in 1983. According to the district's chief judge, pretrial services responsibility was assigned to the probation office because creating another office when probation officers possessed the necessary expertise would have been wasteful. Because the probation office was already overloaded, however, officers now work $30 \%$ overtime in order to provide pretrial services and they spend less time supervising probationers and parolees. Instead of establishing an independent agency, this district requested additional funding for its probation-run program. The request was denied. Only $51 \%$ of its eligible defendants were interviewed before bail hearings during 1984. GAO STUDY, supra note 61, app. I at $10-11$.

79. These districts with independent agencies are: New York Southern; Pennsylvania Eastern; Maryland; Missouri Western; California Eastern; Puerto Rico; Nevada; Florida Southern; and Michigan Eastern. Four of these districts (Pennsylvania Eastern; Maryland; Missouri Western; and Michigan Eastern) began as demonstration independent agencies. Interview with Dan Ryan, Pretrial Ser- 
eral funds. These agencies, as predicted, have shown the most successful delivery of pretrial services. ${ }^{80}$ Since September 1985 , only ten districts have switched from probation-run programs to independent agencies, bringing the total number of independent pretrial services agencies to nineteen. ${ }^{81}$

Most federal districts operating pretrial services through their probation offices cite insufficient funding as the major obstacle to full implementation of the 1982 Pretrial Services Act. They argue that they cannot carry out the congressional mandate without the necessary personnel and resources. ${ }^{82}$ Congress intended federal districts to operate pretrial services through the probation department, however, only where existing personnel were able to carry out pretrial services work. Congress did not intend probation departments to request additional personnel to perform pretrial services. ${ }^{\text {s3 }}$

Official response to districts' implementation choices has been characterized by contradiction. The Administrative Office of the U.S. Courts has supported individual districts' decisions to use probation officers to deliver pretrial services, stating that "staffing needs will be met through the usual budget process."

vices Specialist with the Admin. Office of the U.S. Courts (April 21, 1987).

80. Independently-run agencies continue to operate more effectively than probation-run programs. See Administrative Office of the U.S. Courts, Pretrial. Services Reports for Criminal Defendants Interviewed During the Twelve Month Period Ended June 30, 1986 Table H-1 (1986); see also GAO STUDY, supra note 61. California Central, Georgia Northern, Illinois Northern, and Texas Northern are exceptions; these probation districts operated demonstration pretrial services programs under title II of the 1974 Speedy Trial Act and continue to receive funding.

81. The new independent-agency districts are: California Northern, New Jersey, Pennsylvania Western, Texas Southern, New Mexico, Georgia Northern, Minnesota, Louisiana Eastern, Texas Western, and Missouri Eastern. Interview with Dan Ryan, Pretrial Services Specialist with the Admin. Office of the U.S. Courts (April 21, 1987).

82. See GAO STUDY, supra note 61, at 6-7 (principal reason offered to explain why all criminal defendants are not being contacted before bail hearings is that most judicial districts lack funding sufficient for staff to operate program).

83. See 1984 House Hearings, supra note 70 , at 32; id. at 34 (statement of Chairman Hughes to Mr. James Macklin, Jr., Executive Assistant to Dir. of the Admin. Office of the U.S. Courts) ("If we wanted to give you an authorization to hire and appoint new probation officers to perform pretrial services, we could clearly do that. But we didn't do that."); see also statement of Congressman Hughes, Chairman of House Judiciary Subcomm. on Crime:

I don't know [of] any language that would give the courts discretion to decide . . . whether

they want to handle pretrial services within probation or whether they have to set up a separate pretrial services agency. There was no such discretion given to the courts. If anything, what we said was that if you have resources to handle pretrial services with your other probation work, then handle it within probation. If you don't have resources . . . you have to, at that point, set up a separate agency. 1984 House Hearings, supra note 70 , at 40.

Apparently, some probation officials are fighting the intent of the 1982 Act and the drafters now feel misled. Chairman Hughes commented: "Unfortunately, the Probation Officers Association has done the system and the Congress a grave disservice. There are absolute misrepresentations. Their effort to lead the Congress to believe that there are adequate resources has done a grave disservice to this program and to the court system." Id. at 37.

84. William E. Foley, Dir. of the Admin. Office of the U.S. Courts, Memorandum to federal judicial officers, judicial administrative officials, probation officers, and pretrial services officers (Oct. 14, 1982), reprinted in Implementation of Public Law 97-267 Relating to Pretrial Services: Hear- 
ion which has the effect of encouraging courts to continue their course of implementing the 1982 Act through probation officials. ${ }^{85}$ In contrast, the Congressional Appropriations Committees have provided staff positions and have authorized the appropriation of funds for districts operating pretrial services independently of probation departments. ${ }^{88}$ As a result of this clash between the position of the Administrative Office and the intent of Congress, districts operating probation-run programs are currently not receiving funds for pretrial services.

\section{A New Perspective on Pretrial Services}

The arguments that favored passage of the 1982 Pretrial Services Act remain compelling today; the agencies' services can effectively facilitate pretrial release of many criminal defendants while preserving community safety. Moreover, the program is less expensive than prolonged detention. Indeed, in light of its critical role in ensuring proper administration of the 1984 Bail Reform Act, the 1982 Act should command even more respect today than it did at the time of its enactment.

\section{A. Preventive Detention Under the 1984 Bail Reform Act}

While the 1984 Bail Reform Act authorizes pretrial detention on the basis of dangerousness, this authority is clearly circumscribed by the Act's strict procedural requirements, which mandate full consideration of conditional release prior to an order of detention. ${ }^{87}$ The 1984 Act allows for

ings Before the Subcomm. on Crime of the House Comm. on the Judiciary, 98th Cong., 1st Sess. 19-21 (1983) [hereinafter 1983 House Hearings].

85. The Comptroller General issued a legal decision explaining that neither the 1986 Appropriations Act nor the 1982 Pretrial Services Act compels any restriction on the hiring of additional probation office personnel to provide pretrial services. See U.S. CoMPTROLLER Gen., ANALYSIS: USE OF Appropriaten funds To Pay for additional. Probation Office Personnel To Provide Pretrial Services (August 1986). In an attached letter, however, the Comptroller General advised the Director of the Administrative Office of the U.S. Courts not to ignore the clear intent of the conference committee to restrict the use of appropriated funds. Letter from Milton J. Socolar, Special Assistant to the Comptroller Gen., to L. Ralph Mecham, Dir. of the Admin. Office of the U.S. Courts (Aug. 18, 1986).

86. See S. REP. No. 77, supra note 8, at 9; see also Letter from William J. Hughes to Judge Gerald B. Tjoflat (July 25, 1983), reprinted in 1983 House Hearings, supra note 84, at 47-50 (discussing implementation of 1982 Pretrial Services Act). Chairman Hughes wrote:

Regarding the question of availability of funds, I have the impression that a number of persons in the Federal judiciary are of the opinion that, following the 18-month expansion period, districts will be eligible for additional appropriations to support pretrial services, regardless of whether the services are being provided under the supervision of chief probation officers . . . or under the supervision of a chief pretrial services officer. . . . [The 1982 Pretrial Services Act] states an affirmative policy that additional appropriations for pretrial services are available only for services supervised outside of probation.

Id. at 48; see also 132 Cong. REC. H10,719 (daily ed. Oct. 15, 1986) (appropriations) ("[T]he number of positions provided specifically for pretrial services are exclusively for districts with pretrial services organized outside probation.").

87. The legislative history' of the 1984 Bail Reform Act emphasizes that "the decision to provide for pretrial detention is in no way a derogation of the importance of the defendant's interest in remaining at liberty prior to trial. . . . It is anticipated that [pretrial release] will continue to be appro- 
pretrial detention of only a "small but identifiable group of particularly dangerous defendants"s8 for whom no conditions of release can reasonably assure their appearance at trial and the safety of the community ${ }^{80}$ Chief Justice Rehnquist made it clear in his opinion for the Court in United States $v$. Salerno that the Act requires each contested detention application to lead to a "full-blown adversary hearing" in federal court. ${ }^{90}$ At this hearing, the government must "convince a neutral decision-maker by clear and convincing evidence that no condition of release can reasonably assure the safety of the community or any person."91

Yet while the 1984 Bail Reform Act clearly demands that judicial officers consider a variety of release conditions before ordering detention, many of the Bail Reform Act's supporters focused their oratorical attention on targeting and detaining dangerous offenders. ${ }^{22}$ Legislators sought to respond to the increased publicity of pretrial crime, which had generated widespread outrage and produced pressure for a "tough on crime" congressional attack. ${ }^{93}$ Although the 1984 Bail Reform Act applies only to

priate for the majority of federal defendants." S. REP. No. 225, supra note 3, at 6-7. Moreover, the statutory scheme of 18 U.S.C. $\$ 3142$ continues to favor release over detention, mandating progression from one release option to the next, with pretrial detention only an option of last resort.

88. See S. Rep. No. 225, supra note 3, at 6; see also Letter from Robert A. McConnell, Assistant Attorney Gen., Office of Legislative Affairs, to Sen. Thurmond (April 19, 1983) (in response to request for views of Dep't of Justice on bail reform legislation), reprinted in S. REP. No. 147, supra note 27, app. at 90 (1983). "[I]n our support of this legislation we have never asserted that pretrial detention would be appropriate for more than a small minority of federal defendants, and anticipate that enactment of this legislation would result in only a minor enlargement of the present number of persons subject to detention." Id.

89. 18 U.S.C. \& 3142(e) (Supp. III 1985). Congress adapted this language from the 1966 Bail Reform Act, which allowed pretrial detention of suspects charged with capital offenses punishable by death when "the court or judge has reason to believe that no one or more conditions of release will reasonably assure that the person will not flee or pose a danger to any other person or the community." 18 U.S.C. $\$ 3148$ (1982). The 1966 Bail Reform Act set forth five specific conditions of release, including a "catch-all" that permits imposition of "any other condition deemed reasonably necessary to assure appearance as required." 18 U.S.C. $\S 3146(a)(5)$. The 1984 Bail Reform Act adds nine explicitly stated conditions. "Although each of the additional conditions could appropriately be imposed today under the catch-all in current law, spelling them out in detail is intended to encourage the courts to utilize them in appropriate circumstances." S. REP. No. 225, supra note 3, at 13.

90. 107 S. Ct. 2095, 2103 (1987).

91. Id. The 1984 Act provides:

At the hearing, the person has the right to be represented by counsel, and, if he is financially unable to obtain adequate representation, to have counsel appointed for him. The person shall be afforded an opportunity to testify, to present witnesses on his own behalf, to cross-examine witnesses who appear at the hearing, and to present information by proffer or otherwise. . . . The facts the judicial officer uses to support a finding pursuant to subsection (e) that no condition or combination of conditions will reasonably assure the safety of any other person and the community shall be supported by clear and convincing evidence.

18 U.S.C. $\S 3142(f)$ (Supp. III 1985).

92. For example, Sen. Kassebaum stated: "Given the high rate of recidivism, one of the best methods of reducing violent crime is by getting these offenders off the streets and keeping them off the streets. . . When arrested individuals are let out on bail, there is an unacceptably high probability that they will commit other crimes." 1981 Senate Hearings, supra note 23, at 79.

93. See S. Rep. No. 225, supra note 3. "[The] broad base of support for giving judges the authority to weigh risks to community safety in pretrial release decisions is a reflection of the deep public concern, which the Committee shares, about the growing problem of crimes committed by persons on release." Id. at 6 . 
federal criminal cases, Congress appears to have been influenced largely by statistics on state crime. ${ }^{94}$ Some legislators testified passionately about the problem of crime on bail in certain states and called for strong responsive action. ${ }^{85}$

Overreacting to the rhetoric of individual members of Congress, some judges have failed to adhere to the dictates of the 1984 Act. They have ignored the availability of pretrial services as a powerful mechanism for implementing the Act. In United States v. Colombo ${ }^{96}$ for example, the district court denied the defendant's application for release subject to the imposition of conditions that the defendant believed would be "extremely restrictive, easily enforceable," and sufficient to "assure the community's safety,"97 because it found that the primary purpose of the 1984 Bail Reform Act was to detain dangerous defendants, not to release them on "imaginative conditions." The court noted, "[S]ince clever defense counsel could tailor and propose some combination of restrictive conditions to fit even the most dangerous of defendants, acceptance of such arrangements would result in wholesale circumvention of . . . the Bail [R]eform Act." The 1982 Pretrial Services Act is designed to facilitate fully informed bail

94. The Senate Committee on the Judiciary considered numerous studies regarding rearrest of defendants on pretrial release. See, e.g., Lazar Inst., Pretrial Release: An Evaluation of Defendant Outcomes and Program Impact 48 (1981) (study of release practices in eight states showed that approximately one of six defendants in sample was rearrested during pretrial period, one-third of defendants were rearrested more than once, and some were rearrested four times); see also S. REP. No. 147, supra note 27, at 29-30 (discussing studies of pretrial release). But none of these studies examined federal crime data. Indeed, Congress was aware that crimes prosecuted in federal courts are generally less violent than those subject to state jurisdiction and that federal defendants exhibit a far lower incidence of pretrial crime than their state counterparts. See 1981 Senate Hearings, supra note 23, at 113 (Professor Daniel J. Freed testifying as to lack of crime on bail in federal system as compared with states); 1984 House Hearings, supra note 70, at 180-84.

95. See, e.g., 1981 Senate Hearings, supra note 23, at 2 (Chairman Hatch citing rearrest figures from District of Columbia); id. at 82 (Sen. Bumpers citing crime in State of Arkansas); id. at 56-60 (Sen. Chiles citing dramatic increases in crime rates in Florida and across the country and attributing public outrage at crime rates to lack of confidence in how courts weigh rights of criminals and rights of victims or society). Other members of Congress, such as Rep. Kastenmeier, disagreed:

In my view [an] approach [such as preventive detention] is an overreaction to the nature of the problem of crime on bail in the Federal criminal justice system. Preventive detention has an attractive political ring much like other political slogans currently in vogue. Many of us will be asked on the campaign trail what we have done about crime. Few of us will explain that over $90 \%$ of the street crime is prosecuted at the State level. Fewer of us will argue that we already have the lowest pretrial crime rate within the Federal system.

H.R. ReP. No. 1121, 98th Cong., 2d Sess. 61 (1984).

96. No. 85-244 (E.D.N.Y. Dec. 23, 1985) (order denying release).

97. Id. at 1 . Conditions initially imposed included the defendant's posting $\$ 500,000$ bail to be secured by sureties and a deed to a home, and prohibiting the defendant from (1) associating or communicating with any co-defendant prior to trial except as his lawyer certified was necessary to prepare a defense; (2) appearing at his former place of employment; (3) committing any crime; (4) indirectly threatening a witness or causing harm to anyone; and (5) leaving Orange County except to attend court or consult his attorney. The following additional conditions were suggested and consented to by the defendant: twenty-four hour house arrest; strapping radio transmitter to defendant's wrist; video camera monitoring; inspection of all mail; unannounced visits by law enforcement authorities; and daily reporting by telephone to court's pretrial services unit. Id. at 3, 4, 7-8.

98. Id. at 13 (emphasis in original). 
decisions. It is the judiciary's failure to implement pretrial services that in fact results in the greatest circumvention of the 1984 Act.

Surprisingly, the legislative history of the 1984 Act similarly ignores the function of pretrial services. Although the 1984 Bail Reform Act expresses a strong preference for the least restrictive alternatives to detention, those who drafted the Senate Report failed to emphasize-or even discuss-the essential role of pretrial services in achieving that goal. In addition, the critical connection between pretrial services and preventive detention is also obscured. Nonetheless, the statutory language makes so clear the very important relationship between the 1982 Pretrial Services Act and the 1984 Bail Reform Act that courts are duty-bound to apply it.

\section{B. The Importance of Pretrial Services in the Administration of Bail}

Effective use of pretrial services is essential to the operation of the 1984 Act. The demonstration pretrial services agencies under title II of the Speedy Trial Act ${ }^{90}$ were established to-and did in fact-improve the operation of the 1966 Bail Reform Act. ${ }^{100}$ Since the 1984 Bail Reform Act maintains the insistence of its 1966 precursor on conditional release, pretrial services under the 1982 Act should be considered as vital to the 1984 Act's implementation as were the demonstration agencies to the 1966 Act. Pretrial services would give meaning to both the 1984 Bail Reform Act's preference for release and its provision for detention. A pretrial services report would facilitate structuring of combinations of conditions appropriate for each individual and would also make possible more accurate identification of those few defendants who cannot be safely released on any conditions. $^{101}$

More fundamentally, the extent and quality of pretrial services will determine the direction of future court decisions under the 1984 Bail Reform Act. Successful services will steer courts in the direction of largescale conditional release and accurate, limited preventive detention. Failed

99. Pub. L. No. 93-619, $\S 3152-3156,88$ Stat. 2086, 2088 (1975), amended by 18 U.S.C. $\S \S$ 3152-3155 (Supp. III 1985).

100. See supra notes $47-48$ and accompanying text.

101. See, e.g., United States v. Abrahams, 575 F.2d 3 (1st Cir. 1978) (escaped felon with three previous convictions, who has failed to appear several times and has given false information at previous bail hearings, is "rare case of extreme and unusual circumstances that justifies pretrial detention without bail"). While the 1984 Act was aimed at allowing courts to "address the issue of pretrial criminality honestly and effectively" by permitting authorized, rather than sub rosa, detention of defendants like Abrahams, the accuracy of such detention orders was not explicitly addressed. See S. REP. No. 225, supra note 3, at 11. The in-depth interviews and subsequent recommendations of pretrial services officers would help judges charged with making release or detention decisions. Some judges, however, may believe they have the capacity to make these decisions based on their own experience and from information presented by the parties before them. See GAO STUDY, supra note 61, at 7. But while an examination of the relative merits of subjective and objective frameworks for making decisions suggests tradeoffs between the two, see generally Underwood, Law and the Crystal Ball: Predicting Behavior with Statistical Inference and Individualized Judgment, 88 YALE L.J. 1408, 1422-29 (1979) (discussing advantages of individualized decisionmaking), additional information from an independent, reliable source should be useful to any judge making an individualized determination. 
implementation of pretrial services will lead instead to unnecessary detention.

In United States v. Loren Michael Grey Bear, ${ }^{102}$ a case involving charges of beating, murder, and intimidation of witnesses, the district court properly applied the 1984 Bail Reform Act. It reversed the magistrate's order of detention pending trial, explaining that "it is not possible for the court to find ... that no condition or combination of conditions will reasonably assure the appearance of these ... defendants as required and the safety of any other person and the community." ${ }^{103}$ The district court released the defendants to the custody of the pretrial services office subject to stringent conditions. These included residence in a community treatment center or halfway house, restricted personal associations and movements outside of the center, regular reports to pretrial services officers, avoidance of contact with any potential witness, refraining from the use of alcohol or controlled substances, submission to drug testing as required by pretrial services, and execution of a personal appearance bond. None of the thirteen defendants in this case fled or committed a criminal offense during the period of conditional release. ${ }^{104}$

The case of United States $v$. Young, ${ }^{105}$ on the other hand, demonstrates the 1984 Bail Reform Act's potential for abuse. The district court interpreted the 1984 Act as a virtual mandate for pretrial detention of any person charged with a serious narcotics offense. ${ }^{106}$ The court did not consider any conditions of release, nor did it discuss particular characteristics of the defendants that made them appropriate candidates for detention. The 1984 Bail Reform Act, however, demands that courts detain only defendants for whom no conditions of release could reasonably assure their appearance at trial and the safety of the community. A failure to consider possible release conditions constitutes a clear violation of the Act.

\section{Conclusion}

Lawyers, judges and lawmakers should reexamine the importance of pretrial services to just administration of the federal bail process. Congress should hold oversight hearings on the 1982 Pretrial Services Act, require a detailed report from each district, ${ }^{107}$ and allocate funds to assure the creation and high quality performance of independent pretrial services agencies. The Administrative Office of the U.S. Courts should develop a

102. 636 F. Supp. 1551 (D.N.D. 1986), rev'd, 828 F.2d 1286 (8th Cir. 1987) (appeals court overturned 11 of 13 convictions; new trials ordered for remaining two defendants).

103. No. C2-85-69, order at 3 (D.N.D. Feb. 3, 1985) (order releasing defendants pending trial).

104. Interview with W. Dan Broome, Chief U.S. Probation Officer, D.N.D. (Oct. 5, 1987).

105. 647 F. Supp. 1128 (N.D. Ga. 1986).

106. Id. at 1131 .

107. Congress lacks current information regarding implementation of the 1982 Pretrial Services Act. The only comprehensive survey of all federal districts is the 1985 GAO Study, which showed poor compliance. See GAO STUDY, supra note 61. 
nationwide reporting system to enable federal courts to compare rates of detention, rates of crime on bail and failure to appear, and the availability and performance of pretrial services. Federal judges should establish pretrial services agencies in their districts, and draw on agency reports in each pretrial release determination, or at least in every case in which the possibility of detention, nonappearance or rearrest on bail is raised. Judges should also reevaluate the 1984 Bail Reform Act and apply its mandate for conditional release so as to reduce to the minimum the need for preventive detention. Finally, defense counsel should insist that their clients receive pretrial services interviews and should help shape creative and enforceable conditions that will allow safe release.

Full implementation of the 1982 Pretrial Services Act is crucial to ensuring that the 1984 Bail Reform Act facilitates secure, conditional pretrial release 'where possible and limited preventive detention where necessary. To fulfill its promise of individual liberty and community safety, as well as greater cost efficiency, the statutory design of the 1982 Pretrial Services Act must be respected. 